\title{
Postgraduate nursing students' conceptions on scientific integrity and research ethics
}

\author{
Concepções dos estudantes de pós-graduação em Enfermagem sobre integridade científica e ética na pesquisa
}

Concepciones de los estudiantes de postgrado en enfermería sobre integridad científica y ética en la investigación

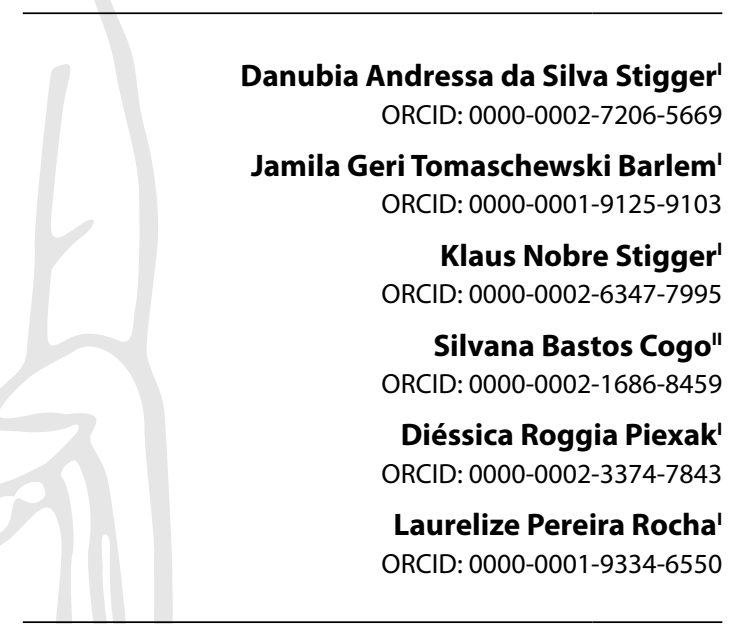

'Universidade Federal do Rio Grande. Rio Grande, Rio Grande do Sul, Brazil. "Universidade Federal de Santa Maria. Santa Maria, Rio Grande do Sul, Brazil.

How to cite this article:

Stigger DAS, Barlem JGT, Stigger KN, Cogo SB, Piexak DR, Rocha LP. Postgraduate nursing students' conceptions on scientific integrity and research ethics. Rev Bras Enferm. 2022;75(3):e20210060. https://doi.org/10.1590/0034-7167-2021-0060

Corresponding author:

Danubia Andressa da Silva Stigger danubiastigger@yahoo.com.br

EDITOR IN CHIEF: Antonio José de Almeida Filho ASSOCIATE EDITOR: Maria Itayra Padilha

Submission: 03-05-2021

Approval: 07-30-2021

\section{ABSTRACT}

Objectives: to understand the conceptions of postgraduate Nursing students regarding integrity in scientific research. Methods: a qualitative, descriptive and exploratory study conducted in October 2020, with 40 students from a postgraduate program in Nursing from a public university in Southern Brazil. The interviews had an emphasis on scientific integrity and its importance for scientific research; they were conducted using synchronous communication tool and analyzed by textual discourse analysis. Results: two categories emerged: "Scientific integrity: the ethical dimension of research" and "Implications of academic productivism for scientific integrity". Such integrity is intrinsically related to the supporting ethical elements, as well as to the nuances of productivism and its impacts on integrity. Final Considerations: the cross-sectionalism of ethical practices is necessary in the production spheres of science, so that knowledge is perpetuated in harmony with integrity and its representations to the community.

Descriptors: Nursing Students; Ethics Research; Nursing Research; Postgraduate Nursing Education; Scientific Integrity Review.

\section{RESUMO}

Objetivos: conhecer as concepções dos estudantes de pós-graduação em Enfermagem sobre integridade em pesquisa científica. Métodos: estudo qualitativo, descritivo e exploratório realizado em outubro de 2020, com 40 estudantes de um programa de pós-graduação em Enfermagem de uma universidade pública do Sul do Brasil. As entrevistas tiveram ênfase na integridade científica e sua importância para as pesquisas científicas; foram realizadas usando ferramenta síncrona de comunicação e analisadas pela análise textual discursiva. Resultados: emergiram duas categorias: "Integridade científica: a dimensão ética da pesquisa" $\mathrm{e}$ "Implicações do produtivismo acadêmico para a integridade científica". Tal integridade mostra-se intrinsecamente relacionada aos elementos éticos de suporte, bem como às nuances do produtivismo e seus impactos para a integridade. Considerações Finais: é necessária a transversalização de práticas éticas nos âmbitos de produção da ciência, para que o conhecimento seja perpetuado em harmonia com a integridade e suas representações para a comunidade.

Descritores: Estudantes de Enfermagem; Ética em Pesquisa; Pesquisa em Enfermagem; Educação de Pós-Graduação de Enfermagem; Revisão de Integridade Científica.

\section{RESUMEN}

Objetivos: conocer las concepciones de estudiantes de postgrado en Enfermería sobre integridad en investigación científica. Métodos: estudio cualitativo, descriptivo y exploratorio realizado en octubre de 2020, con 40 estudiantes de un programa de postgrado en Enfermería de una universidad pública del Sur brasileño. Las entrevistas tuvieron énfasis en la integridad científica y su importancia para las investigaciones científicas; fueron realizadas usando herramienta síncrona de comunicación y analizadas por el análisis textual discursivo. Resultados: emergieron dos categorías: "Integridad científica: la dimensión ética de la investigación" e "Implicaciones del productivismo académico para la integridad científica". Tal integridad se muestra intrínsecamente relacionada a los elementos éticos de base, así como a los matices del productivismo y sus impactos para la integridad. Consideraciones Finales: es necesaria la transversalidad en ética en los ámbitos de producción de la ciencia, para que el conocimiento perpetúe en armonía con la integridad y sus representaciones para la comunidad.

Descriptores: Estudiantes de Enfermería; Ética en Investigación; Investigación en Enfermería; Educación de Postgrado en Enfermería; Revisión de Integridad Científica. 


\section{INTRODUCTION}

The definition of the term "integrity" has its origins in Latin (integritas, atis), that is, it is the state or characteristic of being full, complete, as well as of not having been submitted to manipulations; and, by derivation, it is synonymous with honor and righteousness. Although linked to the characteristics of an unchanged physical existence, it allows the allusion to the abstract bonds of morality and austerity, acquiring protection or safeguarding characteristics, in detriment of extrinsic interventions that may cause damage ${ }^{(1)}$.

Integrity in science can be correlated to values present in scientific research, ensuring a production of knowledge free of dishonesty and reproducing effective results. Thus, moral aspects that converge with honest and transparent results are fundamental characteristics for researchers and professionals involved in the health field. Therefore, the generation of ethically clear knowledge and the repudiation of the possibilities of corruption are part of the praxis of integrity in science ${ }^{(2)}$.

In this sense, scientific transparency is fundamental for research to be effectively reverted to the community. Based on an integrative literature review, the main motivations for misconduct were justified by issues linked to individual vanity, such as recognition and prestige, coupled with a substantial competitive sense arising from the need for production ${ }^{(3)}$.

Regarding the academic productivism, it is relevant to think critically about the hasty productions, governed by quantitative logic. Thus, the aspects that foster this productivism should be widely discussed, since, if on the one hand the attitudes of integrity and ethics are required and monitored, on the other hand, this thinking cannot be indifferent to the context of promoting science, which involves the need to produce. Thus, preparation for a science driven by the premises of integrity cannot be dissociated from critical and reflective thinking on the theme and its representations in the scientific sphere ${ }^{(4)}$. That said, in-depth analyses of integrity are needed, involving technical and scientific discussions of the topic and encompassing the academic sphere and public organizations as a whole ${ }^{(5)}$.

Thus, the relevance of educational spaces in this context is highlighted, as well as the student's protagonism, going beyond the ethical principles and bureaucratic regulations demanded by the academic activities, which also contributes to their performance as a human and social being ${ }^{(6-7)}$. To this end, it is essential to encourage conduct that integrates values and good practices in the academic field, continuously, through initiatives that mitigate scientific dishonesty ${ }^{(6)}$.

Furthermore, the importance of studies involving ethics and integrity in science within the training environment is emphasized, in order to foster the enrichment of knowledge and thus enable interventions to strengthen the transparency and credibility of science. This justifies this research.

Given the above, the following research question emerges: What are the conceptions of postgraduate nursing students about integrity in scientific research?

\section{OBJECTIVES}

To understand the conceptions of postgraduate nursing students regarding integrity in scientific research.

\section{METHODS}

\section{Ethical Aspects}

The research was approved by the Research Ethics Committee (REC), respecting the legal determinations of Resolution 510/16, which regulates research in the area of Human and Social Sciences $^{(8)}$. It was made available and presented to the participants, who spontaneously adhered, guidelines for signing the Informed Consent Form (FICT) electronically.

\section{Type of study}

The methodology used to construct this study was qualitative, exploratory and descriptive, guided by the guidelines of the Standards for Reporting Qualitative Research: a Synthesis of Recommendations (SRQR) instrument ${ }^{(9)}$.

\section{Methodological Procedures}

\section{Study scenario}

The research was conducted in October 2020, in the Nursing Postgraduate Program of a public university in the South Region of Brazil, which has concept 5 by the Coordination for the Improvement of Higher Education Personnel (CAPES). This postgraduate program started in 2001, and the first admissions to the master's course occurred in 2002. Regarding the doctorate course, it started in 2009. The teaching staff is composed of 17 professors, of which 15 are permanent and 2 collaborators. There are 101 postgraduate students enrolled, of whom 59 are PhD students, and 42 Master's students.

\section{Data source}

Forty students participated in the study. Among them, 22 doctoral students and 18 master's students, contemplating different areas of professional training, such as Biology, Law, Nursing, and Medicine. Inclusion criteria were established as follows: to be duly enrolled, in the year 2020, in the master's or doctoral course of the Postgraduate Program in Nursing. Exclusion criteria: being on sick leave or maternity leave; having requested course withdrawal.

\section{Collecting and organizing data}

As a data collection method, the semi-structured interview was chosen, encompassing open-ended questions, with emphasis on scientific integrity and its importance for scientific research. The interviews were conducted by the researcher, with the aid of a synchronous communication tool, in real time, with an average duration of 30 minutes; they were audio recorded and later transcribed for analysis. The selection of the postgraduates was by non-probabilistic sampling by convenience or access, so that it occurred according to availability. The researcher organized the available public according to their potential contribution to the study ${ }^{(10)}$. The quantity of the sample was based on the adherence of students to the research, considering the data necessary for a consistent analysis and interpretation, thus meeting the 
proposed objectives. The contacts persisted for three attempts and, in the case of no response and/or impossibility of express participation; the students were disregarded as participants, according to exclusion criteria. Anonymity was guaranteed and preserved, using for this purpose the letter M (master's student) or D (doctoral student) and the respective year in the course, followed by a number representing the order in which the interview was conducted.

\section{Data analysis}

For data analysis, it was used the Textual Discourse Analysis, which comprised the following phases: in a first moment, the material was submitted to a thorough optics and fractionated so that the analysis allowed the understanding of smaller textual units that complete the meaning of the information, in a process known as "unitarization". In the second step, defined as categorization, the units of meaning obtained in the first process were grouped considering their representations from the interpretation, resulting in two categories: "Scientific integrity: the ethical dimension of research"; and "Implications of academic productivism for scientific integrity". In the third stage, understood as the exteriorization of the new understanding, the categorized information was interpreted from the perspective of an empirical dialogical action focused on the author's understanding and supported by theoretical bases pertinent to the theme involved ${ }^{(11)}$.

\section{RESULTS}

With the data analysis, two categories emerged that encompass in an organized way the results of the described analysis, contemplating the glimpses of scientific integrity from the perspective of the postgraduates and relating them to a specific content of intrinsic correlation and complementary connotation, regarding the conceptions of integrity.

\section{Scientific integrity: the ethical dimension of research}

In this category, results were obtained from a reflection on integrity with respect to the ethical dimension that permeates the ways of constructing and reproducing science. It should be added that the most varied nuances reflect the understanding of the category analyzed, broadening the view of ethics and integrity in its literal concept, under the student's understanding, which glimpses scientific integrity consistently, essentially and intrinsically related to the supporting ethical elements that constitute it.

However, it is worth noting the existence of ideological variations between the concepts, expressing equivalence, doubt, and even complete distinction, which no less importantly fosters reflections on integrity, ethics and morality, as well as their representations for scientific research.

I cannot be a person of integrity without being ethical. Ethics is linked to integrity [...]. (D3.2)

I'm not sure [...]. I think integrity is much more related to morals than to ethics... I'm not sure. These are concepts that are not quite clear to me. (M2.2)
For me, him being ethical is very different from him being righteous [...]. (M2.10)

In a complementary manner, the view of integrity when linked to the production of science emerged in a systematic way, associating itself with good practices related to the methodological rigor of research, encompassing technical, normative and ethical issues in the relationship with the participants. This representation is also substantiated through the perception of the appropriate use of mechanisms to ensure the complete safety of each participant.

Integrity in the data that is going to be collected, so it won't be cheated, integrity in the content that is going to be exposed, making that content true, I believe that's it [...] do a thorough research, in a correct way. (D1.1)

I think about this, the question of respecting the autonomy of this person, the risks, the benefits. I think in this sense, more involving ethical aspects of research. (M1.1)

Therefore, the establishment of an inverse relationship between integrity and the breaking of the methodological rigor of research remained constant in the reports, making emphatic the differences that associate integrity with the total repudiation of practices that deconstruct credibility and science.

In addition, elements related to individual morality and professional values of the researcher were listed, giving rise to inferences that the concept of integrity may be related to subjective values shaped in each individual. Thus, the need to have knowledge about the area was cited as fundamental to sustain the concept of integrity, highlighting the role of the researcher in the scientific field and his or her responsible role in conducting health research.

I think there is no way to have integrity without being ethical, because integrity is a moral value, honesty, integrity is very much linked to honesty. It is I since know why I am here, how I relate with my fellow researchers, how I relate with the object of my research. (D3.2)

Knowing the theme, respecting it, knowing the limitations, the rights and the duties of the people he comes in contact with on a daily basis, or that he is researching and knowing that the results will be properly worked on, that is, he will not create a bias, he will not have deviations of purpose. (D2.7)

Similarly, the conception of integrity is perceived from a more altruistic perspective, directly related to the commitment of postgraduates with the production of science for society. Thus, aspects such as trustworthiness, impartiality and reliability are often associated with integrity. A point of emphasis refers to the completeness of research regarding the ability of the researcher to synthesize information, but keeping in focus the main idea, which corroborates the elements of reliability and quality. Therefore, the aforementioned components complement the perception that integrity in research is related to its potential to transform realities, benefiting health in a global manner that is, highlighting the importance of the application of knowledge production in health practices.

There are times when I think about what we are producing and what we are managing to change in our practice, because I see, 
especially in our area, a very large bridge and, for me, this bridge, every day that passes, becomes more distant from research and assistance, for example. (D2.9)

Therefore, it is emphasized, based on the conceptions, the importance of the researcher organizing a process of self-reflection, including the articulation with the execution time and receptivity in relation to the transformations that may occur along the way, so that the desired objectives do not deviate from the commitment with the social return and materialize naturally in a production imbued with empathy, originality and credibility. Moreover, the relevance of neutrality is observed, so that the researcher can enter the research ethically, reflecting the behavior in the science produced and reproduced a posteriori.

I think that commitment is one of the most important factors. The other is discernment, which has to be enough to keep you in line and understand what will add to you or not, if it takes you out of your plummet, your integrity and the ethics that you believe you have built. And, a third attribute [...] is the availability [...] understand that sometimes, if you stay on a path that goes against integrity and ethics you have to take more time, because you have to retrace this path more than once. (D1.3)

\section{Implications of academic productivism for scientific integrity}

In this category, the theme was analyzed based on the assumptions that factors related to academic production systems can influence integrity and its perpetuation in scientific research. In this context, essential elements that constitute the pillars of integrity are listed, based on the premises of quality, consistency of the material produced, and its implications for society and science. Thus, issues such as egocentrism search for visibility, productivism and conflicts of interest are mentioned as the main influencers of scientific integrity in academic productions. Moreover, it should be noted that the student-teacher relationship helps to mediate this process, permeating the commitment, security and development model of postgraduates, in the march towards the progress of science and researchers along the paths of integrity.

In view of this, the need for production as a substantial factor is emphasized, often associated with ruptures of integrity due to a variable number of factors. This condition, from the point of view of many postgraduates, recurrently overrides the quality of productions and interventions in the scientific field. It is emphasized that academic productivism, in particular, becomes an impacting factor on the ways of developing science.

At the postgraduate level, I see a need for volume of output; and often this amount of volume compromises integrity precisely because integrity demands time and dedication. (D2.5)

We need quantitative, I know we need it, but there should be a way for the evaluating agencies to evaluate us in a different way, these issues of cooperation [...] because otherwise we do a lot of quantity with little quality. (D1.6)

However, it was observed, concomitantly, the understanding of the need for productivism to feed a global system, very present in the academic field, which transcends the doors of postgraduate studies, in which teachers are also subjected to intense pressures to maintain production and quality.

We know that unfortunately, through common sense, we even end up explaining that it is unethical, but ifyou don't do it, the system overrides you [...]. There are things that happen for the course to survive, to give marks in the postgraduate course. All this pressure the professors show us, because they also suffer. (M2.7)

Moreover, the consequences of productivism can be even more harmful, beyond disrespect, methodological weaknesses and incipient quality, since the development of systems and the social dynamics itself, in terms of health care policies, are nourished by the integrity of scientific research. It is noteworthy that the "ethical cracks" resulting from productivism can culminate in chaotic and potentially serious impacts that go beyond the realms of academia.

If you think in the context of the pandemic that we have been experiencing, there was some research that, right afterwards, had to be published. Butwesaw that somemedications, like hydroxychloroquine, did not have the desired effect as we wanted, and this influences people a lot. [...] You have to be aware of the research you are going to do, if it is not going to cause any harm as well. (D1.1)

In this context, predatory journals and their respective editorial boards that foster biased and self-centered behavior stand out, collaborating to the inadequate feeding of this production system. Easy-to-publish practices of fragile rigor are encouraged and perpetuated, potentially encouraging cycles of dishonesty that erode integrity in the most varied forms.

It is the meeting of necessity and opportunity that is leading to several activities and researches that end up with important alterations in their course, in the integrity of their researchers, in the ethical conduct and, mainly, in the publications of their results. I think that another factor that has collaborated in a very important way is the fact that these publications today have become a little easier in online journals without any kind of control [...] so it is capitalism, it is greed, it is the vanity of having a large number of publications, or views and citations, which eventually may even have been bought. (D1.3)

On the other hand, it is worth mentioning that the culture of quantitative production is superimposed on that of quality, permeating the principles of the scientific community globally. This is because the exacerbated demand for the scientific product converges in a subtle way with the conflicts of interest represented by means of advantages, beyond the personal level, involving business groups, institutions, and representations of financial fomentation with interest in health investigations.

[...] I could say that corruption occurs only because of money, but I think there is much more than that [...] this pressure for the number of publications can cause the lack of integrity of the researcher, maybe financial goals, numerical goals of publications can corrupt the researcher. You have several social, economic, cultural factors. (D2.7)

The importance of transparent conduct by the researcher also emerges, allowing the inference that, despite the existence of deep-rooted corruption in the scientific field, it is possible to 
conduct the production of science in a pure manner, consistent with ethics and integrity in scientific research and its application to health, which also implies a teaching/discerning commitment to the search for integrity.

Because you have to produce, of course produce, but not to excel in quantity, but in the quality of the research. [...] when we opt for postgraduate studies, we know that there is a certain social responsibility and, for this very reason, that this research has to have quality, because we are going to have an impact on people's lives. (M2.5)

Corroborating the above, in the following statement, one notices the discomfort and dissatisfaction with the approach and conduction model of some academic researches, which may imply a "hurry" in the organization of the investigations.

[...] the girl started to question me, I was in the middle of the shift and then I stopped [...]. I think that if she had warned us, in advance it would have been much better both her result and my performance. (M2.10)

The content of this category complements the understanding of the theme by exposing the nuances of productivism and its impacts. This reinforces the need for the cross-sectionalism of ethical practices in all areas of science production, so that knowledge is built and perpetuated in constant harmony with integrity and its representations to the community.

\section{DISCUSSION}

The concept of integrity in research encompasses a set of behaviors that encompass the conduct of research from a perspective that emphasizes the purpose and responsibility of the scientist as a professional ${ }^{(12-13)}$, aiming at the production and articulation of knowledge in a virtuous way for the benefit of the collectivity ${ }^{(13)}$. Thus, the conceptions of integrity that emerged among the postgraduate students in this study permeate the concepts of ethics and morality, intrinsically related to the particular way in which each individual understands the proper way to construct, conduct and replicate knowledge.

In this context, the juxtaposition between the concepts, described in the Canadian Committee on Research Integrity's code, involving the dimensions of ethics and scientific integrity becomes relevant, since integrity breakdowns are recurrently intimately connected with the corrupting practice of ethics in science ${ }^{(14)}$. It is noteworthy that the understandings pointed out in the analysis contemplate a tenuous association between ethics and integrity, highlighting the latter as a pillar for scientific research. That said, from the standpoint of postgraduate students, these concepts are sometimes viewed with the same meaning, without the perception of a conceptual difference when applied to scientific practices.

However, despite a solid approximation, ethics and integrity in research permeate different ideologies. While the former is directed toward ensuring the connections of investigative conduct with the prevailing and socially accepted ethical norms, the latter refers to values that involve bureaucratic and normative issues, such as behaviors, attitudes, conducts, transcending ethics dynamically in the entirety of the research design processes ${ }^{(14)}$.

Thus, the understanding of scientific integrity involves compliance with standardized norms supported by ethical conduct at all stages of research, and also involves the transparent performance of the researcher, respecting autonomy and taking responsibility for the veracity of the information collected and the outcomes achieved. It also relates to ethically acceptable behavior, maintaining neutrality in the face of conflicts of interest and ensuring the independence of the profession ${ }^{(1)}$. In this sense, issues emerge that are rooted in morality, honesty and transparency in relation to the researcher, which constitute fundamental elements for the elaboration and support of an integral conception, solidified in the rigor of ethics and scientific standardization.

It should be added that the management of knowledge and its application for the benefit of humanity is configured as an instrument of great importance and represents an advance for all. However, the contamination of scientific practices by inappropriate conduct and untruthful information impact the purposes of science and the development of society to the detriment of the entire population ${ }^{(15)}$. Therefore, the use of knowledge in the practical application of health was evidenced and reported as an essential factor, when considering the understanding of integrity and its relevance to research. Moreover, it is evident in the statements that the conduct of the researcher needs to be based on impartiality, represented by the absence of personal interference of any kind. Thus, these elements and their correlations become essential for scientific integrity to be reflected also in the results presented and their resulting transformations.

The second category explores the views about productivism in academia from various perspectives. In this context, it is emphasized that factors such as the oppression of science production systems ${ }^{(16-17)}$ and the quest for prestige and profit ${ }^{(17)}$ can be connected to integrity deviations ${ }^{(16-17)}$. It is noteworthy that such productivism to which teachers, students and universities are subjected can significantly drive poor quality science, represented in various forms and intensities.

It becomes pertinent the allusion of productivism linked to a capitalist reason in which the systematic productions confer gains and prestige to their mentors. The transposition to the academic reality in the postgraduate course context entails, to professors and universities, the mission to produce more and more. On one hand, this mechanistic behavior implies physical and psychological changes, culminating in damages to the teachers' health, who quickly succumb to the logic of "publish or perish"(18-19). On the other hand, from a partially optimistic perspective, this system can drive students to produce materials that will add value to the scientific environment and, in turn, contribute positively to society ${ }^{(20)}$, which justifies the postgraduates' understanding of the need for productivism.

However, it is worth pointing out the paradox that emerges in this context, because this need very often turns knowledge into a product ${ }^{(19-20)}$ and academic relations in market competitions. Moreover, the damage is not restricted to the extent that postgraduates also become vulnerable to the consequences of productivism, which are psychological, organic and social problems $^{(20)}$. 
Another issue refers to the quality of the produced material, considering the current postgraduate course evaluation model, which is given by the predominance of quantitative metrics. It becomes pertinent that associated qualitative and quantitative forms of evaluation be considered in the criteria of the development and control institutions, so that quantity and quality reflect a harmonious relationship for the benefit of science ${ }^{(21)}$. This issue corroborates the postgraduates' understanding of the importance of quality, but in balance with the need for production and visibility of knowledge. Moreover, it ratifies the understanding that, although productivism is potentially harmful to the academic context, it is possible to perpetuate researchers committed to integrity, overcoming the reason of the "mercantilist" production of knowledge.

Therefore, one of the aspects involving the publication process of a scientific material concerns the reviewers, who act in the judicious evaluation of the article's content, as well as in the analysis of the technical and ethical consistency ${ }^{(22)}$. At the same time, the editors who coordinate the journals have the responsibility and commitment to ensure the quality of the publications, in the sense that they have much to contribute towards scientific integrity ${ }^{(23)}$. Meanwhile, the postgraduates associate the influence of misconduct and predatory journals with productivism and the corrosion of integrity in scientific production.

It should be added that academic productivism is used as a lever for easy publication journals ${ }^{(24)}$ with a mostly financial focus, and the consequences impact the potential visibility of a material that is fragile in terms of ethics and integrity, since the evaluation processes are inconsistent or sometimes absent ${ }^{(25)}$.

Thus, it is evident, in this study, a shared commitment, within which the postgraduate course plays a key role, to perpetuate the integrity in research, through the attitude of teachers and the classes taught, as well as the dynamics of the supervisor and the relationship established with the students. The importance of the academic sphere is emphasized when it comes to the full understanding of the methodological steps, of the rights and duties of researchers and participants. The conceptions analyzed can be extended to the understanding of the need for ethical and integral care regarding the approach during the conduction and operationalization of scientific research.

The postgraduate courses in Brazil are registered, evaluated and promoted by the Coordination of Higher Level Personnel (CAPES), a federal organization connected to the Ministry of Education that acts in the recurrent monitoring of the scientific production, correlating the grades granted with production indicators, among other evaluative bases ${ }^{(26)}$. Still, the forms of evaluation of postgraduate programs in the country are not organized in a simplistic way, based on quantitative logic; in fact, qualitative aspects of evaluation are overshadowed in the interstices of academia, succumbing to the metric valorization of knowledge production ${ }^{(27)}$.

It is ratified that, in the academic context, with the constant increase in research productivity, the quality of technical papers gives way to the quantity of publications ${ }^{(28-29)}$. However, the postgraduates associated the conceptions of integrity in the academic field not only to aspects related to the quantity of production, but also to personal and institutional interests that may be linked to financial support and the visibility of mutual benefit.
In this sense, conflicts of interest can be characterized as a situation in which the simultaneity between the focus of science and the interest of other origins becomes perceptible and potentially biased, to the detriment of the necessary neutrality for scientific conducts. The scenario can be represented by existing connections between researchers and other agents that provide financial, personal, commercial, among other conveniences ${ }^{(30)}$.

To this end, it is important to understand the culture of integrity within the academic universe, taking into account that ethics expands to the social and professional environment, that is, it transcends the educational environment. Thus, in addition to internal conducts that reiterate and perpetuate the application of ethics in academic training, it is emphasized that teaching practices significantly determine, beyond the professional, the human being, the protagonist in shaping ethics and morality in today's society and beyond ${ }^{(31)}$.

It is added that good scientific practices, as well as the perpetuation of integrity in the academic training environment, should be disseminated by teaching and research organizations, encouraging autonomous and reflective processes ${ }^{(32)}$. Furthermore, it becomes extremely valid to reflect on the strengthening of ethics in the curricular bases, with the purpose of mitigating inappropriate practices ${ }^{(33)}$.

Therefore, integrity in scientific production was highlighted as part of research ethics, suggesting reflections on the relationships of students and teachers for the construction of knowledge solidified in ethically appropriate conducts, overcoming the negative influences represented by productivism, conflicts of interest, academic vanity and competitiveness.

\section{Study limitations}

The conceptions expressed in this study cannot be explored under a common perspective, since they integrate visions characteristic of the students of the postgraduate program analyzed. Thus, it becomes opportune and enriching that further studies on the subject are developed, allowing correlations and comprehensive conclusions.

\section{Contributions to the Area}

The article fosters reflections about the understanding of scientific integrity, as well as the potential corrosion factors related to academic productivism, which hinder the development and transparency of research. Furthermore, the paper allows a reflection on the scientific sphere and ways to conduct knowledge, driving good practices concomitant to good science.

\section{FINAL CONSIDERATIONS}

It is concluded that integrity is understood by a set of personal inferences, and it is also dared to mention a possible cross-sectionalism to the extent that it can be evidenced in the protagonism of the researcher, in the mutual respect between participants and researchers, in the relationship between peers, in the commitment to effective social return and, especially, in the scientific constructions perpetuated and replicated in postgraduate educational spaces. The mention of academic productivism emerged expressively in the reports, which expresses a palpable 
discomfort in relation to the production systems present in scientific spaces. It is worth mentioning the evidence of a crystal clear understanding of the need for the quality of the material produced to override quantitative metrics, making transparent the awareness about integrity and what it represents for the perpetuation of knowledge, for health and for society.

Therefore, this study meets the proposed objectives, demonstrating that integrity has its bases in the formalization of rules of methodological rigor, but is much more directed to the essence of each individual, reiterating the mutual commitments that permeate scientific and human relationships. In summary, it is possible to glimpse the most varied nuances, as well as the inseparable ethical constructs that characterize being with integrity and the application of this integrity in research, inferring that integrity in science, from the perspective of postgraduates, cannot be conceptualized in isolation.

\section{SUPPLEMENTARY MATERIAL}

Article derived from a master's thesis available from: https:// ppgenfermagem.furg.br/dissertacoes-e-teses/publicacoes-de2020/12947dissertacao-danubia-andressa-da-silva-stigger

\section{REFERENCES}

1. Neves MCP. On (scientific) integrity: conceptual clarification. Med Health Care and Philos. 2018;21(2):181-7. https://doi.org/10.1007/ s11019-017-9796-8

2. Goulart BNG, Levey S, Rech RS. The role of ethics and research integrity in the training of health professionals and in the development of human research. Rev CEFAC. 2018;20(5):561-4. https://doi.org/10.1590/1982-0216201820513518

3. Costa Aznar FD, Freitas Asznar AR, Capelari MM, Costa Aznar FD, Sales-Peres SHC, Sales-Peres A. Neutralidade científica: aspectos éticos na obtenção de resultados. Rev Latino-Am Bioét. 2017;17(33-2):31-41. https://doi.org/10.18359/rlbi.1899

4. Vilaça MM. Más condutas científicas uma abordagem crítico-comparativa para in-formar uma reflexão sobre o tema. Rev Bras Educ. 2015;20(60):245-69. https://doi.org/10.1590/S1413-24782015206012

5. Pádua GCC, Guilhem D. Integridade científica e pesquisa em saúde no Brasil: revisão da literatura. Rev Bioet. 2015;23(1):124-38. https://doi. org/10.1590/1983-80422015231053

6. Casado M, Martín MM, Neves MCP, coordinators. Declaració sobre ètica i integritat en la docència universitària [Internet]. Barcelona: Edicions de la Universitat de Barcelona; 2018[cited 2020 Oct 07]. Available from: http://diposit.ub.edu/dspace/handle/2445/119580

7. Denat Y, Dikmen Y, Arslan GG. Ethical values of academic nurses: a pilot study. Nurs Ethics. 2019;26(6):1744-52. https://doi. org/10.1177/0969733018774613

8. Conselho Nacional de Saúde (BR). Resolução n॰ 510, de 7 de abril de 2016. Aprova as diretrizes e normas regulamentadoras de pesquisas em ciências humanas e sociais [Internet]. Brasília, DF: CNS; 2016[cited 2020 Oct 15]. Available from: http://conselho.saude.gov.br/ resolucoes/2016/Reso510.pdf

9. O'Brien BC, Harris IB, Beckman TJ, Reed DA, Cook DA. Standards for reporting qualitative research: a synthesis of recommendations. Acad Med. 2014;89(9):1245-51. https://doi.org/10.1097/ACM.0000000000000388

10. Gil AC. Métodos e técnicas de pesquisa social. 7a ed. São Paulo: Atlas; 2019.

11. Moraes R, Galiazzi MC. Análise textual discursiva. 2a ed. ljuí: Unijuí; 2016.

12. Simões E. A declaração de Singapura e a questão da integridade ética na pesquisa científica. Thaumazein. 2018;11(22):63-83.

13. Santos LHL. Sobre a integridade ética da pesquisa. Cienc Cult. 2017;69(3):4-5. https://doi.org/10.21800/2317-66602017000300002

14. Le comite canadien de l'intégrité de la recherche. État des politiques sur l'intégrité et l'inconduite en recherche au Canada [Internet]. Ottawa; HAL; 2009[cited 2020 Oct 07]. Available from: http://www.frqs.gouv.qc.ca/documents/10191/186009/Etat_politiques_integrite_ Canada_2009.pdf/45f8ee74-022c-483f-8e28-bcc45f015913.

15. Severino AJ. Implicações éticas da construção do conhecimento: desafios para a prática da docência e da investigação científica. Rev Nesef. 2017;6(1):59-70. https://doi.org/10.5380/nesef.v6i1.59522

16. Guazi TS, Laurenti C, Carrara K. Boas práticas científicas: uma discussão analítico-comportamental. Interac Psicol. 2018;22(1):1-9. https://doi. org/10.5380/psi.v22i1.54143

17. Satur RV, Dias GA, Silva AMBM. Direito autoral, plágio e coautoria: questões acadêmicas e éticas. Brazilian Journal of Information Science [Internet]. 2020 [cited 2020 Nov 19];14(1):57-87. Available from: https://dialnet.unirioja.es/servlet/articulo?codigo=7340412

18. Andrade JS, Cassundé FR, Barbosa MAC. Da liberdade à "gaiola de cristal": sobre o produtivismo acadêmico na pós-graduação. Perspect Gestao Conhecimento. 2018;9(1):169-97. https://doi.org/10.21714/2236-417X2019v9n1

19. Farias Júnior RS. "Publish or perish": o produtivismo acadêmico e o adoecimento docente. Rev Cocar [Internet] 2020[cited 2020 Oct 12];14(28):644-63. Available from: https://periodicos.uepa.br/index.php/cocar/article/view/3142

20. Estácio LSS, Andrade WGF, Kern VM, Cunha CJCA. O produtivismo acadêmico na vida dos discentes de pós-graduação. Questao. 2019;25(1):133-58. https://doi.org/10.19132/1808-5245251.133-158 
21. Gamboa SS, Chaves-Gambo M. A produção científica no sistema de pós-graduação brasileiro: os desafios da avaliação qualitativa. In: CIAIQ2019: atas investigação qualitativa na educação. Lisboa: CIAIQ; 2019[cited 2020 Oct 12]. Available from: https://www.proceedings. ciaiq.org/index.php/CIAIQ2019/article/view/2392

22. Rego STA, Oliveira SAB, Rocha AD, Carvalho AL, Morits ÂFE, Lima CEPGV, et al. Guia de integridade em pesquisa da Fiocruz [Internet]. [Rio de Janeiro]: Fiocruz; 2019[cited 2020 Oct 12]. Available from: https://www.arca.fiocruz.br/handle/icict/41188

23. Committee on Publication Ethics. Code of conduct and best practice guidelines for editors [Internet]. Eastleigh: COPE; 2011 [cited 2020 nov 12]. Available from: http://publicationethics.org/files/Code_of_conduct_for_journal_editors_Mar11.pdf

24. Carvalho ESS, Santos Júnior HP. Publish and perish: predatory journals' threat to scientific integrity Rev Baiana Enferm. 2019;33:e34649. https://doi.org/10.18471/rbe.v33.34649

25. Clark J, Smith R. Firm action needed on predatory journals. BMJ. 2015;350:h210. https://doi.org/10.1136/bmj.h210

26. Marenco A. When institutions matter: CAPES and political science in Brazil. Rev Cienc Polit (Santiago). 2015;35(1):33-46. https://doi. org/10.4067/S0718-090X2015000100003

27. Santos FA, Marques HJ. A avaliação da pós-graduação brasileira e a produção do consenso ativo. Intermeio [Internet]. 2018 [cited 2020 Nov 25];24(47):123-45. Available from: https://periodicos.ufms.br/index.php/intm/article/view/5907

28. Fischer J, Ritchie EG, Hanspach J. Academia's obsession with quantity. Trends Ecol Evol. 2012;27(9):473-4. https://doi.org/10.1016/j. tree.2012.05.010

29. Lima JM, Vanti Vitullo NA. Produção científica e produtivismo acadêmico no processo avaliativo da pós-graduação brasileira. Bibliocanto (Natal). 2019;5(1):18-41. https://doi.org/10.21680/2447-7842.2019v5n1ID18423

30. Fundação de Amparo à Pesquisa do Estado de São Paulo. Código de boas práticas científicas [Internet]. São Paulo: FAPESP; 2012 [cited 2020 Nov 28]. Available from: https://fapesp.br/boaspraticas/FAPESP-Codigo_de_Boas_Praticas_Cientificas_2014.pdf

31. Almeida F, Seixas A, Gama P, Peixoto P, Esteves D. Fraude e plágio na universidade: a urgência de uma cultura de integridade no ensino superior. Coimbra: Imprensa da Universidade de Coimbra; 2016. https://doi.org/10.14195/978-989-26-1123-5

32. Silva NRA, Pádua GCC, Novaes MRCG, Guilhem DB. Scientific integrity among nursing students participating in the scientific initiation program: an exploratory study. Rev Esc Enferm USP. 2020;54:e03548. https://doi.org/10.1590/s1980-220x2018047703548

33. Barbosa QF, Rodrigues CS, Novaes MRCG. Scientific integrity in the education of health professionals. Rev Bioet.2019;27(1):120-6. https://doi. org/10.1590/1983-80422019271294 